\title{
GEORGI MAMARCZEW - BOHATER WALK O WYZWOLENIE BUŁGARII PIERWSZEJ POŁOWY XIX WIEKU1
}

\author{
BARTŁOMIEJ RUSIN
}

\begin{abstract}
AвSTRACT. Georgi Mamarchev - the hero of the fight for the liberation of Bulgaria in the first half of the 19th century.

The aim of the article is to show the selected forms of political and military activity of Georgi Stoikov Mamarchev (1786-1846), the iconic Bulgarian national fighter. The main attention is dedicated to G. Mamarchev's involvement in Russian-Turkish wars (1806-1812; 1828-1829) and the uprising in the Turnovo region in 1835 (the so-called Velchova zavera). Thanks to G. Mamarchev's activity against Ottoman Empire, during the Bulgarian National Revival period (1762-1878) he was regarded as one the first and most influential Bulgarian freedom fighter. In the following decades he was showed in the context of political activity of his nephew Georgi S. Rakovski (1821-1867).
\end{abstract}

STReSzCzenIE. Artykuł omawia meandry życia jednego z najważniejszych bułgarskich bojowników o wolność pierwszej połowy XIX wieku Georgiego Stojkowa Mamarczewa (1786-1846). Autor nie rekonstruuje pełnej biografii tej postaci, skupiając się na kwestii udziału Mamarczewa jako ochotnika w wojnach rosyjsko-tureckich toczonych w latach 1806-1812 oraz 1828-1829, a także wydarzeń związanych z przygotowywanym powstaniem w okręgu tyrnowskim w 1835 roku (Wełczowa zawera). Zdaniem autora, dzięki swojemu konsekwentnemu zaangażowaniu w działania zbrojne przeciwko Imperium Osmańskiemu można uznać Mamarczewa za jednego z pierwszych, a zarazem najważniejszych „zawodowych” bojowników o wolność w epoce bułgarskiego odrodzenia narodowego (1762-1878). W kolejnych dekadach ten sposób walki o wyzwolenie ziem bułgarskich spod władzy tureckiej zaprezentował w pełni jego siostrzeniec Georgi S. Rakowski.

Autor: Bartłomiej Rusin, Uniwersytet Jagielloński, Instytut Historii, ul. Gołębia 13, 31-007 Kraków, Polska, bartlomiej.rusin@gmail.com, ORCID iD: https://orcid.org/0000-0003-1282-4878

Słowa kluczowe: Georgi Mamarczew, wojny rosyjsko-tureckie, Wełczowa zawera, historia Bułgarii, bułgarskie odrodzenie narodowe

Keywords: Georgi Mamarchev, Russian-Turkish wars, Velchova zavera, history of Bulgaria, Bulgarian National Revival

Balcanica Posnaniensia. Acta et studia, XXVII, Poznań 2020, Wydawnictwo Wydziału Historii UAM, pp. 8196, ISBN 978-83-66355-54-5, ISSN 0239-4278. Polish text with summaries in English and Polish.

doi.org/10.14746/bp.2020.27.6

1 Artykuł powstał w ramach projektu badawczego finansowanego przez Narodowe Centrum Nauki w Krakowie: Bałkańskie procesy migracyjne w XIX wieku. Przypadek Butgarii i Serbii (2017/25/N/ HS3/00576). 
W historii bułgarskiego ruchu narodowowyzwoleńczego pierwszej połowy XIX wieku nie brakowało jednostek, które walkę o wyzwolenie ojczyzny podjęły przy użyciu oręża, a nie dostępnych wtedy metod politycznych ${ }^{2}$. Dotyczyło to zarówno osób, które opuściły ziemie bułgarskie i udały się na emigrację już wcześniej, jak również tych, którzy zmuszeni zostali do wyjazdu w związku z toczonymi działaniami zbrojnymi, czy to będących wynikiem buntów paszów tureckich, czy też kolejnych wojen rosyjsko-tureckich toczonych w XVIII i XIX wieku ${ }^{3}$. Jednym z nich był Georgi Stojkow Mamarczew Bujukliu (1786-1846, w rodzimej historiografii znany najszerzej jako Georgi Mamarczew), którego aktywność jako bojownika o wyzwolenie narodowe postaramy się tutaj prześledzić. W związku z tak zarysowanym tematem artykułu, autor czuje się zwolniony z obowiązku rekonstruowania pełnej biografii tego działacza, ograniczając się jedynie do przywołania podstawowych faktów z jego życiorysu, zainteresowanych odsyłając do najpełniejszej jak dotąd monografii poświęconej osobie Mamarczewa ${ }^{4}$. W historiografii bułgarskiej istnieje obszerna literatura poświęcona opisywanej postaci ${ }^{5}$, jak również poszczególnych wydarzeń z dziejów Bułgarii pierwszej połowy XIX wieku. Szczególnym zainteresowaniem badaczy cieszy się okres pierwszej połowy lat trzydziestych, stanowiący okres samodzielnych przygotowań Bułgarów do powstania w okręgu tyrnowskim, w których Mamarczew

2 Bułgarzy prowadzili działalność polityczną na rzecz wyzwolenia swojej ojczyzny niemalże od początku XIX wieku. W pierwszym okresie największe zasługi w tym dziele miał przede wszystkim biskup wraczański Sofroniusz, który po emigracji na ziemie rumuńskie i wybuchu wojny rosyjsko-tureckiej w 1806 roku podjął szeroko zakrojone działania na rzecz popularyzacji kwestii bułgarskiej w Rosji (przy wydatnym udziale misji dyplomatycznej Iwana Zambina i Atanasa Nekowicza w tym kraju) oraz akcji werbowania ochotników do armii rosyjskiej. zob. V. Račeva, V"prositelni okolo političeska deinost na Sofronii Vračanski, „Istoriya”, 1995, бp. 1, s. 31-40; V. Zlatarski, Političeska rolya na Sofronii Vračanski prez rusko-turskata voina 1806-1812 g., „Godišnik na Sofiiskiya Universitet. Istoričeski Fakultet” 1923, t. 19, nr 3, s. 1-85; P. Mitev, Političeskata deinost na Sofronii Vračanski v konteksta na Novoto vreme, w: Sofronii Vračanski - knižovnik i politik ot novoto vreme. Sbornik s materiali ot meždunarodna naučna konferenciya, Sofiya, 24 noemvri 2011 g., red. P. Mitev, V. Račeva, Sofiya 2013, s. 124-135; V. Zlatarski, P"rvite ,, b"lgarski deputati” $v$ Rusiya, ,B”lgarska istoričeska biblioteka” 1928, t. 3, s. 109-129.

$3 \mathrm{Na}$ ten temat zob. V. Mutafčieva, A. Vianu, Feodalnite razmirici v Severna B"lgariya v kraya na XVIII i načaloto na XIX v. i tyahnoto otraženie v"v Vlahiya, w: B"lgaro-rum "nski vr"zki i otnošeniya prez vekovete, t. 1, Sofiya 1956; C. Genov, B"lgarite i rusko-turskite voini XVIII-XIX vek, Sofiya

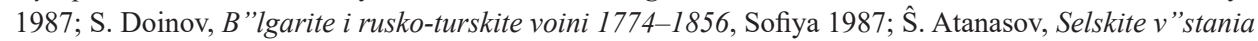
v B "lgariya k"m kraya na XVIII v. i s"zdavaneto na b"lgarskata zemska voiska, Sofiya 1958.

4 K. V"zv"zova-Karateodorova, Kapitan Georgi Mamarčev 1786-1846, Sofiya 1986. Autorka już wcześniej zajmowała się bliżej postacią Mamarczewa, poświęcając mu m.in. dwa artykuły biograficzne. Zob. K. V"zv"zova-Karateodorova, Georgi Mamarčev, w: Beležiti B"lgari, t. 2, 1396-1878, red. S. Mitev, G. Gatev, G. Ginčev, N. Malčev, H. Uzunov, Sofiya 1968, s. 99-106; K. V"zv"zova-Karateodorova, Dobavki k"m biografiyata na kapitan Georgi Mamarčev - kapitan Georgi Bujukliu (okolo 1786-1846 g.), w: V pamet na akademik Mihail Dimitrov. Izsledvaniya v"rhu B "lgarskoto v"zraždane, red. E. Stoyanova, Sofiya 1974, s. 215-221.

5 Jednym z najnowszych opracowań jest książka Iwana Pyrwanowa poświęcona hajdukom i wojewodom w historii bułgarskiej, wśród których została umieszczona również osoba Georgiego Mamarczewa. Zob. I. P"rvanov, Haiduti. B"lgarskite voivodi do kraya na XIX vek, Sofiya 2020, s. 130-134. 
brał czynny udział. Jedna z badaczek tematu Wanja Raczewa podkreśla w swoim tekście, że w zasadzie wszyscy uczeni bułgarscy są zgodni co do tego, że dotychczas wykorzystywana baza źródłowa jest w znacznym stopniu niewystarczająca, zaś materiały o charakterze wspomnieniowym lub publicystycznym są niepewne. Raczewa wskazuje również, że niejednokrotnie interpretacja przez historyków wydarzeń związanych ze sprzysiężeniem Wełczo Atanasowa (a zatem i roli, jaką w organizacji spisku odegrał Mamarczew) była zależna od bieżącej koniunktury politycznej w całym $\mathrm{XX}$ wieku' ${ }^{6}$. Podobnie rzecz ma się, jeśli idzie o wcześniejsze wydarzenia z życia bułgarskiego patrioty, dotyczące chociażby kwestii, czy naprawdę piastował stanowisko dowódcze w czasie wojny rosyjsko-tureckiej z lat 1806-1812. Większość badaczy powołuje się w tym przypadku na przekaz pozostającego pod ogromnym wpływem swojego wuja Georgiego Rakowskiego, którego dokonania naukowe - jak udowodniono - obecnie nie mają już większej wartości naukowej

Georgi Stojkow Mamarczew przyszedł na świat najprawdopodobniej w 1786 roku we wsi Koteł (dziś miasto), miejscu będącym jednym z najważniejszych rodzimych ośrodków odrodzenia narodowego. To stąd wywodziło się wielu działaczy politycznych i rewolucyjnych, m.in. biskup Wracy Sofroniusz (właśc. Stojko Władisławow, ok. 1739-1813), Neofit Bozweli (1785-1848), Christo Botew (1848-1876), czy też największy rewolucjonista bułgarski XIX wieku Georgi Stojkow Rakowski (18211867), którego łączyły z Mamarczewem więzy pokrewieństwa. Siostra Mamarczewa Rusa Popowicz była matką Rakowskiego. Postać Mamarczewa i związany z nią mit walki zbrojnej o wyzwolenie uciemiężonej ojczyzny miały być jednym z głównych czynników, pod wpływem których kształtował się charakter małoletniego jeszcze wtedy Rakowskiego ${ }^{8}$. Na osobowość młodego Mamarczewa wpływ wywarła również z pewnością atmosfera domu rodzinnego - jego ojciec aktywnie uczestniczył w życiu społeczno-politycznym lokalnej wspólnoty, a także brał udział w niektórych walkach o charakterze zbrojnym, np. w czasie starć z oddziałami tureckimi w pobliżu wsi Esziolu (dziś Zelena Morawa) w 1809 roku. W młodości Mamarczew mógł też mieć jakieś kontakty z późniejszym biskupem Wracy Sofroniuszem, dzięki któremu zapoznał się z Histora stowianobutgarska mnicha chilendarskiego Paisija, z odpisu sporządzonego w 1781 roku9 .

${ }^{6}$ V. Račeva, Velčovata zavera (1835 g.) vogledaloto na b"lgarskata istoriopis, w: Predizvikatelstvata na promyanata. Nacionalnata naučna konferenciya, Sofiya, 10-11 noemvri 2004, red. I. Baeva, P. Mitev, Sofiya 2006, s. 149-159.

7 V. Traikov, G.S. Rakovski. Biografiya, Sofiya 1974, s. 376.

8 V. Traikov, op. cit., s. 55-57. Dość powiedzieć, że to pod wrażeniem dokonań swojego wuja Rakowski zmienił otrzymane na chrzcie imię Sybi (Sawa) na imię Georgi, pod którym znany jest w rodzimej historii. Zob. K. V"zv"zova-Karateodorova, Dobavki k"m biografiyata, s. 216.

9 K. V"zv"zova-Karateodorova, Kapitan Georgi Mamarčev, s. 31-33. Ukończoną przez mnicha Paisija w 1762 roku „Historię słowianobułgarską” uznaje się za początek epoki rodzimego odrodzenia narodowego. Jednego z pierwszych odpisów książki dokonano we wspomnianej wyżej wsi Koteł w 1765 roku. Zob. S. Romanski, Georgi Mamarčev i dobrovolčeskata mu komanda ot 1828-1829 g., „Spisanie na BAN” 1921, t. 22, s. 175. 
Mamarczew przeniósł się za Dunaj najpewniej około 1806 roku, kiedy ziemie bułgarskie opuszczały znaczne grupy ludności, w związku z niepokojami społecznymi, a także w oczekiwaniu na wybuch wojny Turcji z Rosją. Było to zjawisko właściwe dla szerszej grupy Bułgarów, którzy po niepokojach i buntach dostojników tureckich uciekali na Wołoszczyznę i do Rosji już od początku XIX wieku ${ }^{10}$. Według innej z wersji Mamarczew zdecydował się na emigrację po zabójstwie czorbadży Bożiła, który nie cieszył się popularnością wśród miejscowej ludności. Brakuje jednak dokumentów potwierdzających, że był on w jakikolwiek sposób zamieszany w sprawę jego śmierci. Równie problematyczna pozostaje kwestia ustalenia miejsca jego osiedlenia, najprawdopodobniej były to tereny dolnego biegu Dunaju ${ }^{11}$.

Dla Mamarczewa konflikt z lat 1806-1812 stanowił w rzeczywistości chrzest bojowy. Wojska rosyjskie, uprzedzając wypowiedzenie wojny przez Imperium Osmańskie, wcześniej zajęły całe terytorium księstw naddunajskich, poza kilkoma punktami umocnionymi na lewym brzegu Dunaju, m.in. twierdzą w Izmaile, którą udało się zdobyć dopiero we wrześniu 1809 roku. W międzyczasie nie prowadzono poza tym żadnych poważnych działań zbrojnych, po zamordowaniu sułtana Selima III priorytetem dla władz tureckich było opanowanie pogłębiającej się anarchii w państwie. Ponadto, od sierpnia 1807 roku obowiązywał zawarty w Slobozii rozejm rosyjsko-turecki, który przetrwał prawie dwa lata - działania wojenne wznowiono w marcu 1809 roku. Stan armii rosyjskiej zwiększył się w tym czasie do 80 tys. żołnierzy, a głównodowodzącym został książę Aleksander Prozorowski, który opracował nowy plan opanowania broniących się twierdz, a następnie sforsowania Dunaju i wkroczenia na ziemie bułgarskie ${ }^{12}$.

Dokument zezwalający na tworzenie oddziałów ochotniczych spośród emigrantów został wydany jeszcze w styczniu 1806 roku, co od razu przyciągnęło ku armii rosyjskiej sporą grupę chętnych do walki. Wśród nich znalazł się również Georgi Mamarczew, niektórzy zresztą upatrują powodu jego emigracji z ziem bułgarskich właśnie w związku z wydanym pismem urzędowym, podkreślając motywy patriotyczne i chęć uczestnictwa w batalii o wyzwolenie ojczyzny u młodego emigranta bułgarskiego. Bułgarom powierzono szereg różnorodnych zadań: mieli stanowić ochronę obozów, dostawców zaopatrzenia dla wojska i furażu dla zwierząt oraz środków transportu, wywiadowców, przewodników jednostek zbrojnych, tłumaczy kancelaryjnych, a wreszcie także ochotników walczących u boku Rosjan. Jednym z tych ostatnich miał być również Mamarczew, obejmując dowództwo jednego z oddziałów ochotniczych w 1812 roku, wedle słów swojego siostrzeńca Rakowskiego: samowol-

10 V.P. Gračev, K"'m v"prosa za preselvaneto na b"lgari v Rusiya v načaloto na XIX v. (1800-1806), w: B'lgarskoto v"zraždane i Rusiya, red. V.D. Konobeev i dr., Sofiya 1981, s. 264-289.

11 K. V"zv"zova-Karateodorova, Kapitan Georgi Mamarčev, s. 35-36.

12 Więcej na temat kampanii z lat 1807-1809 zob. A. Petrov, Voina Rossii s Turciei 1806-1812 gg., t. 1, Sankt-Peterburg 1885, s. 122-362; A. Petrov, Voina Rossii s Turciei 1806-1812 gg., t. 2, SanktPeterburg 1887, s. 1-537. 
nych Bułgarów ${ }^{13}$, w toku walk wykazując się odwagą, za co został nagrodzony orderem św. Jerzego ${ }^{14}$. Wśród historyków bułgarskich zdania na ten temat są jednak podzielone. Jednym z pierwszych, który wyraził niepewność w tej kwestii był historyk Stojan Romanski, pisząc, że watpliwe jest, aby w tym okresie doszedt on [Georgi Mamarczew - B.R.] do stanowiska dowódcy bułgarskich ochotników ${ }^{15}$. Także badaczka Kiriła Wyzwyzowa-Karateodorowa stwierdza, że dotychczas nie udowodniono, czy Mamarczew zajmował stanowisko dowódcze (w swoim tekście cytuje po raz kolejny Rakowskiego) ${ }^{16}$. Z kolei inni uczeni uznają, że już podczas tej wojny rosyjsko-tureckiej Mamarczew miał pod swoją komendą oddzielną jednostkę. Jednym z nich jest Petyr Czołow, który również powołując się na powyższy ustęp z dzieła Rakowskiego pisze: Powstała [czeta Georgiego Mamarczewa] po przekroczeniu Dniestru przez wojska rosyjskie jesienia 1806 roku i rozpoczęciu okupacji Besarabii, Mołdawii i Wołoszczyzny. Jej istnienie potwierdził także Georgi S. Rakowski przed ponad 140 laty. Pisze on, że jego wuj Georgi Stojkow Mamarczew Bujukliu, urodzo$n y w$ Kotel, $w$ czasie tej wojny byt dowódca samowolnych Bułgarów. Nie mamy świadectw dotyczacych szlaku bojowego czety, informacji o liczbie ochotników ani też ich imion i nazwisk ${ }^{17}$. Podobnie Stefan Dojnow wymienia w swojej książce dowódców oddziałów sformowanego w 1811 roku bułgarskiego wojska ziemskiego, gdzie obok Christo Kosjakoglu, hadżiego Penczo, hadżiego Kulewa, znalazło się również nazwisko Georgiego Mamarczewa. Liczebność jednostki w szczytowym momencie wynosiła około 2 tys. ochotników ${ }^{18}$, a Mamarczew był jednym z dowódców piechoty ${ }^{19}$. Za dowódcę ochotników (znów za Rakowskim) uznał Mamarczewa także Conko Genow $^{20}$. Ze względu na brak zachowanych źródeł, kwestii tej nie jesteśmy w stanie rozstrzygnąć jednoznacznie. Większość cytowanych wyżej badaczy opiera się w swoich opracowaniach na relacji Georgiego Rakowskiego, który zafascynowany postacią swojego wuja mógł dokonać „upiększenia” jego biografii, aby tym bardziej uwypuklić jego zasługi dla wyzwolenia Bułgarii z niewoli tureckiej. Jak już powiedzieliśmy we wstępie, biograf Rakowskiego podkreśla, że z dzisiejszej perspektywy dokonania naukowe tego rewolucjonisty bułgarskiego nie przedstawiają większej wartości, a ich znaczenie przejawiało się przede wszystkim w uświadamianiu i aktywizacji ówczesnej inteligencji do podjęcia walki narodowowyzwoleńczej ${ }^{21}$. Można zatem przyjąć,

13 Wszystkie tłumaczenia na język polski, jeśli nie zaznaczono inaczej, zostały wykonane przez autora artykułu.

14 G.S. Rakovski, S"čineniya. Proza. Poeziya, t. 1, red. K. Topalov, Sofiya 1983, s. 359.

15 S. Romanski, V’staničeski načinaniya na kapitan Goergi Mamarčev Bujukliu, w: Sbornik po slučai stogodišninata na Zaverata ot 1835 g., Sofiya 1935, s. 42.

16 K. V"zv"zova-Karateodorova, Georgi Mamarčev, s. 101.

17 P. Čolov, B'lgarskite v"or"ženi četi i otryadi prez XIX vek, Sofiya 2003, s. 14.

18 Conko Genow podaje liczbę 5 tys. ochotników bułgarskich spośród w sumie 20 tys., pochodzących ze wszystkich krajów bałkańskich. Zob. C. Genov, op. cit., s. 60.

19 S. Doinov, op. cit., s. 83.

20 C. Genov, op. cit., s. 57.

21 V. Traikov, op. cit., s. 376. 
że w czasie wojny rosyjsko-tureckiej 1806-1812, biorąc pod uwagę młody wiek oraz brak doświadczenia bojowego u Mamarczewa, początkowo nie dowodził on własną jednostką, a komendę objął dopiero pod koniec konfliktu, co zgadzałoby się z wersją Rakowskiego, piszącego, że sprawował dowództwo w $1812 \mathrm{roku}^{22}$. Biorąc pod uwagę fakt, że traktat pokojowy w Bukareszcie podpisano w maju tego samego roku, ewentualna nominacja Mamarczewa miała charakter przede wszystkim symboliczny.

Pomoc Bułgarów okazała się szczególnie ważna po przekroczeniu linii Dunaju, kiedy działali już w ramach utworzonego przez Rosjan bułgarskiego wojska ziemskiego, którego dowódcą mianowano gen. Pawła Turczaninowa. Oddział Mamarczewa, operujący w okolicach twierdzy Silistra, został latem 1811 roku nagrodzony przez głównodowodzącego wojsk rosyjskich na froncie bałkańskim gen. Michaiła Kutuzowa za działania rozpoznawcze i wywiadowcze. Jesienią tego samego roku wsławił się on z kolei podczas szturmu tej twierdzy tureckiej - znajdując się w awangardzie, śmiało starł się z wojskami tureckimi i oddziałem janczarów, zadając przeciwnikowi znaczne straty. Czyny Bułgarów osobiście chwalił w swoim raporcie gen. Michaił Kutuzow, pisząc do cara rosyjskiego Aleksandra I: (...) świeżo sformowane oddzialy Butgarów wzięty udziat $w$ walkach, pokazując, że warte sq okazanej przez Wasza Wysokość opieki $^{23}$.

Wojenne zaangażowanie Bułgarów nie skończyło się bynajmniej wraz z zakończeniem działań bojowych i podpisaniem traktatu pokojowego w Bukareszcie w maju 1812 roku. Bułgarskie wojsko ziemskie jeszcze pod koniec tego samego miesiąca zostało rozformowane, co dla większości ochotników oznaczało de facto koniec walki zbrojnej, a jednocześnie ogromne rozczarowanie - warunki pokoju bukareszteńskiego nie przyniosły praktycznie żadnych korzyści zniewolonemu narodowi bułgarskiemu. Co więcej, Petersburg, nie chcąc dodatkowo utrudniać ułożenia na nowo swoich stosunków z Konstantynopolem, tonował nastroje rewolucyjne wśród emigrantów służących w armii rosyjskiej. Jednocześnie, w związku z zagrożeniem ze strony napoleońskiej Francji sformowano nową jednostkę, w skład której weszło około 4 tys. żołnierzy, częściowo również Bułgarów z rozformowanego wojska ziemskiego. Oddziały te brały udział w walkach nad Berezyną, a później również w słynnej „bitwie narodów" pod Lipskiem w październiku 1813 roku. Niektórzy badacze sugerują, że Mamarczew uczestniczył w zmaganiach bojowych tej wojny, wiadomo natomiast z pewnością, że dowódcą był tam jeden z jego przyjaciół Dymityr Watikiotis ${ }^{24}$.

W tym miejscu na dobrą sprawę urywa się ślad aktywności Mamarczewa na emigracji. Brak dokumentów oraz materiałów o charakterze wspomnieniowym uniemożliwia rekonstrukcję tego okresu życia naszego bohatera. Przyjmuje się, że mógł on zamieszkać w Mołdawii lub na Wołoszczyźnie, gdzie doczekał wybuchu powstania

22 G.S. Rakovski, op. cit., s. 359.

23 Feldmaršal Kutuzov. Sbornik dokumentov i materialov, red. N.M. Korobkova, Moskva 1947, s. 130. Cyt. za: C. Genov, op. cit., s. 60 (tu w języku bułgarskim).

24 K. V"zv"zova-Karateodorova, Kapitan Georgi Mamarčev, s. 42-43. 
greckiego w 1821 roku $^{25}$. Na czele powstania stanął Aleksander Ipsilanti, a w szeregach walczących znalazło się znaczne grono Bułgarów - emigrantów, którzy osiedlili się na ziemiach rumuńskich w różnym okresie. Spośród wyróżniających się dowódców bułgarskich w walkach zapisali swe nazwiska między innymi bracia Dimityr i Paweł Makedonski. Jak stwierdza przywoływany już wcześniej Stojan Romanski, także Mamarczew niewątpliwie wstąpił w szeregi powstańców, i to jako jeden z dowodzących. Świadczyć o tym ma fakt, że od tego momentu posługiwał się on własną pieczęcią, zawierającą jego nazwisko, rok, w którym została przygotowana - 1821, oraz wizerunek św. Jerzego świadczący o tym, że posiadał to odznaczenie wojskowe. W trakcie kolejnej wojny rosyjsko-tureckiej 1828-1829 Mamarczew posługiwał się tą pieczęcią przy wydawaniu oficjalnych dokumentów ${ }^{26}$. W zachowanym spisie ochotników znalazło się również nazwisko odnotowane jako Giorgios Bujguka, czy też „Bujuka” (pamiętajmy, że w tym okresie zaczął on posługiwać się nazwiskiem Bujukliu) które mogło należeć do Mamarczewa. Jeden z historyków bułgarskich zajmujących się dziejami powstania greckiego z 1821 roku w ogóle jednak nie wspomina w swojej monografii nazwiska Georgiego Mamarczewa, brakuje go również w spisie bułgarskich ochotników pomieszczonym w aneksie książki ${ }^{27}$.

Po kilkuletniej nieobecności na scenie dziejów, Georgi Mamarczew włączył się aktywnie w działania kolejnej wojny rosyjsko-tureckiej, uzyskując zgodę gen. Piotra Wittgensteina na sformowanie własnego oddziału jeszcze w kwietniu 1828 roku. Drugim obok Mamarczewa dowódcą został mianowany Panajot Fokjanow (lub Fokjano). W skład jednostki wchodziło początkowo około 275 osób, z których połowę stanowiła piechota, drugą połowę natomiast konnica. Większość stanowili Bułgarzy, nie brak było jednak przedstawicieli innych narodowości, w tym przede wszystkim Rumunów, Greków, Albańczyków czy Serbów ${ }^{28}$. Kolejne oddziały powstawały na Wołoszczyźnie również w tym i następnym roku, jak np. oddział Miłko Petrowicza, składający się z około 200-osobowej grupy Bułgarów, Rumunów, Serbów i Greków, walczących później w okolicach miasta Szumla (dziś Szumen). Oddziały ochotnicze powstawały również wzdłuż północnego brzegu Dunaju, a ich zadaniem było nękanie wojsk tureckich, szczególnie na terenach położonych bardziej na Zachód, gdzie nie dotarła jeszcze armia rosyjska, po przekroczeniu rzeki w Dobrudży ${ }^{29}$.

W pierwszym etapie wojny ochotnicy Mamarczewa prowadzili działania wzdłuż linii Dunaju, między miastami Silistra i Rusczuk (dziś Ruse), początkowo bez zgody ze strony dowództwa rosyjskiego. Zadaniem oddziału było przerwanie, a w przy-

25 S. Romanski, V'staničeski načinaniya, s. 43.

26 Ibidem.

27 N. Todorov, Balkanski izmereniya na gr"ckoto v"stanie 1821: prinos"t na b"lgarite, Sofiya 1984, s. 67-75; N. Todorov, V. Traikov, Gr"ckoto v”stanie ot 1828-1829 g. i b"lgarite, „Istoričeski Pregled” 1971, t. 2, s. 3-34.

28 N. Žečev, B"lgarskata emigraciya v Rum"niya XIV v. - 1878 g., Sofiya 1986, s. 245-246; S. Doinov, op. cit., s. 101-103.

29 N. Žečev, B"'lgarskata emigraciya, s. 246-247. 
padku, gdyby nie było to możliwe, utrudnienie dostaw amunicji i zaopatrzenia drogą wodną z Rusczuku do broniących się w twierdzy silistreńskiej oddziałów tureckich. Oddział Mamarczewa wywiązał się z nawiązką z tej misji, rozbijając załogi tureckie na wysepkach na Dunaju nieco powyżej miasta. To właśnie za ten czyn otrzymał od cara rosyjskiego Mikołaja I order św. Anny i drogocenną szablę ${ }^{30}$. Kampania 1828 roku nie przyniosła decydującego rozstrzygnięcia, w związku z czym po zdjęciu oblężenia Silitry większość wojsk odesłano na kwatery zimowe na Wołoszczyznę. Jednostce Mamarczewa powierzono w tym czasie zadanie patrolowania północnego brzegu Dunaju na odcinku między tą twierdzą i miastem Tutrakan, na wypadek ewentualnych ataków tureckich ${ }^{31}$.

W marcu 1829 roku oddział Mamarczewa został wchłonięty przez nowo utworzony korpus pod dowództwem gen. Iwana Liprandiego. Nastąpiło rozdzielenie jednostki na dwie części: konnica pod dowództwem Fokjanowa operowała w okolicach miast Silistra - Hadżiogłu Pazardżik (dziś Dobricz) - Szumla. Natomiast oddział piechoty pod dowództwem Mamarczewa patrolował z kolei okolice Szumli, a w sierpniu 1829 roku wszedł do walki z oddziałami baszybuzuków w rejonie wsi Wetren. Jeszcze na przełomie sierpnia i września tego roku rozgromili oni też oddziały tureckie pod dowództwem paszów Kolczakoglu i Saryczoglu, jak również posiłki wysyłane im na pomoc z twierdzy w Rusczuku. Następnie korpus został skierowany w rejon Silistra Tutrakan, gdzie do momentu swojego rozformowania w listopadzie 1829 roku pełnił funkcję wysuniętej osłony oddziałów rosyjskich na prawej flance. Brakuje informacji, czy kapitan Mamarczew brał udział we wszystkich tych walkach. Biorąc jednak pod uwagę jego dotychczasową działalność i zaangażowanie od pierwszych dni konfliktu należy przyjąć, że był on jednym z bardziej aktywnych bułgarskich uczestników zmagań wojennych między Turcją i Rosją ${ }^{32}$. Potwierdzają to również zaszczyty, jakie spotkały Mamarczewa za udział w kampaniach 1828 i 1829 roku - order oraz szabla, wysłana osobiście przez cara rosyjskiego Mikołaja I, o czym wspomina siostrzeniec bojownika, Georgi Rakowski ${ }^{33}$. Należy też pamiętać, że walki te miały de facto charakter epizodyczny i nie zadecydowały one w większym stopniu o suk-

30 K. V"zv"zova-Karateodorova, Kapitan Georgi Mamarčev, s. 56-58.

31 Ibidem, s. 58-59.

32 K. V"zv"zova-Karateodorova, Kapitan Georgi Mamarčev, s. 60-63; R. Boev, B'lgarskiyat dobrovolčeski korpus v ruskata armiya ot 1829 g., ,Voennoistoričeski sbornik” 1978, t. 4, s. 82-90; R. Boev, B'lgarite v rusko-turskata voina $1828-1829$ g., „Izvestiya na Nacionalniya voenno-istoričeski muzei” 1980, t. 4, s. 62-72; S. Romanski, Georgi Mamarčev i dobrovolčeskata mu komanda, s. 175-207. Inne zdanie w tej kwestii prezentuje historyk Konstantin Weliki, który pisze o chorobie Mamarczewa, która uniemożliwiła mu kontynuowanie swoich obowiązków jako dowódcy od lata 1829 roku. Od tego momentu aż do końca wojny oddziałem kierował płk. Liprandi. Zob. K. Veliki, Neizdadeni dokumenti i nyakoi utočneniya v"v vr"zka s kapitan Georgi Mamarčev Buyuklyu, w: idem, Stranici ot minaloto na b"lgarskiya narod, Sofiya 1987, s. 114. Nie oznacza to bynajmniej, że Mamarczew nie brał udziału w starciach zbrojnych toczonych do końca wojny, tym bardziej uzyskane odznaczenia świadczą o jego zaangażowaniu i wysokiej ocenie, jaką uzyskał ze strony dowództwa rosyjskiego.

33 Cyt. za: V. Traikov, op. cit., s. 57. 
cesie armii rosyjskiej, od wiosny 1829 roku operującej na ziemiach na południe od gór Stara Płanina. Miały one jednak ważny wpływ na postawy ludności, rozbudzając w Bułgarach powoli świadomość własnej odrębności kulturalnej i narodowej, a także pobudzając ich do walki zbrojnej i powstańczej, przede wszystkim na ziemiach południowo-wschodnich ${ }^{34}$. Zachował się również spis ochotników wchodzących w skład oddziału Georgiego Mamarczewa z wojny lat 1828-1829, zawierający w sumie 109 nazwisk $^{35}$.

Brak zapisów gwarantujących prawa i swobody dla ludności bułgarskiej w traktacie pokojowym z Adrianopola (2/14 września 1829 roku) sprawił, że część ochotników podjęła decyzję o kontynuowaniu walki zbrojnej. Jednym z nich był Mamarczew, który planował wzniecenie powstania we wschodniej Bułgarii, skąd miało ono rozprzestrzenić się na wszystkie ziemie bułgarskie. Wspierała go w tej idei część rewolucyjnie nastawionych mieszkańców miasta Sliwen i jego rodzinnej wsi Koteł. W celu przygotowania powstania Mamarczew rozesłał emisariuszy, których zadaniem była rekrutacja chętnych do walki oraz organizacja broni i środków finanso-

34 V.D. Konobeev, B'lgarskoto nacionalnoosvoboditelno dviženie. Ideologiya, programa, razvitie, Sofiya 1972, s. 259-271; R. Boev, Antiturskoto dviženie na naselenieto ot b'lgarskoto černomorsko kraibrežie prez rusko-turskata voina $1828-1829$ g., ,,Voennoistoričeski sbornik” 1970, t. 5, s. 18-38.

$35 \mathrm{Na}$ liście oprócz samego dowódcy znaleźli się: 1. Awram Pyrwanow, 2. Aleksandyr Czokoj, 3. Angeł Genow, 4. Angeł Neszkow, 5. Angeł Stefanow - później osiedlił się w Piteszti, 6. Andrej Iwanow, 7. Andrej Jankow, 8. Anton Iwanow, 9. Batko Rusew z Razgradu, 10. Wasił Batew, 11. Wasił Iwanow, 12. Wasił Nenkow z Koteł, 13. Wasił Neszkow, mieszkaniec Bukaresztu, 14. Wełko Petrow, 15. Wojko Nikolaew, 16. Gani Nedełczew, 17. Ganczo Nikołow, 18. Gaco Iwanow, 19. Genczo Cwetkow, 20. Georgi Bogdanow, 21. Georgi Dimitrow, 22. Georgi Nikow, 23. Georgi Pawłow, 24. Georgi Prokłow, 25. Georgi Tofan, 26. Gica Dimitrow, 27. Grigor Andreew, 28. Grigor Dimitrow, 29. Grigor Iwanow, 30. Danko Danczow, 31. Dimityr Aleksandrow, 32. Dimityr Ganczew, 33. Dimityr Iwanow, 34. Dimityr Neszkow, 35. Dmityr Nikolaew (Nikołow), 36. Dimityr Radkow, 37. Dimityr Czernew, 38. Dimo Kostadinow, 39. Dica Georgijew, 40. Dragan Georgijew, 41. Dragit Radow, 42. Iwan Georgijew, 43. Iwan Dobrodżan z Dobrudży, 44. Iwan Konstantinow, 45. Iwan Manew, 46. Iwan Marinow, 47. Iwan Michedincew, 48. Iwan Petkow, 49. Iwan Sawczew, 50. Iwan Stefanow, 51. Iwan Todorow, 52. Iwan Czolaka, 53. Iwanica Wizetow, 54. Iwanica Georgijew, 55. Iwanica Iwanow, 56. Iwanica Popow, 57. Iwanczo Nikołow, 58. Iwanczo Stefanow, mieszkaniec Ploeszti, 59. Iwanczo Filipow, 60. Ilija Pawłow, 61. Ilija Tomow, 62. Kalin Włachin, 63. Koljo - pochodzący z miasteczka Osman Pazar (dziś Omurtag), 64. Konstantin Kris, 65. Konstantin Stanew, 66. Kosta Dimitrow, 67. Kosta Milew, 68. Manczo Markow, 69. Marin Badew, 70. Marin Zacharijew, 71. Minko Deczew, 72. Nikoła Anastasow, 73. Nikoła Andreew, 74. Nikoła Stefanow, 75. Nikoła Stojanow, 76. Nikołaj Grigorow, 77. Niczo Marinow, 78. Opriszan Widżoj, Wołoch z Oltenicy, 79. Panajot Popow, 80. Panko Iwanow, 81. Petyr Wrażiłow, 82. Petyr Ducow, 83. Petyr Iwanow, 84. Petyr Oprew, 85. Petyr Petrow, 86. Petyr Trajstarow, 87. Rad Antonow, 88. Spiro Ilijkow, 89. Stan Nikołow, 90. Stanjo Marinow, 91. Stefan Wyłczew, 92. Stefan Mutrin, 93. Stojko Genow, 94. Stojko Manojłow, 95. Stojan Dimow, 96. Stojan Kurtew, 97. Stojan Markow, 98. Stojan Nikołow, 99. Stojan Petkow, 100. Tanas (Atanas) Bojczew, 101. Todor Sandow, 102. Toma Mateew, 103. Toma Rusczuklijata z Ruse, 104. Fiłczo Georgijew, 105. Christo Doczew, 106. Janaki Josifow, 107. Jani Balew, 108. Janko Panajotow. Zob. P. Čolov, op. cit., s. 22. Wskazuje się, że po oddzieleniu konnicy Fokjanowa od piechoty Mamarczewa jednostka liczyła w szczytowym momencie do 116 ochotników, co oznacza, że prezentowany tutaj spis nazwisk stanowi prawie pełny wykaz wszystkich walczących. Zob. K. Veliki, Neizdadeni dokumenti, s. 113. 
wych. Działania te spotkały się ze zdecydowaną krytyką opcji umiarkowanej, na czele z dr. Iwanem Seliminskim (1800-1867), która optowała za emigracją Bułgarów na Wołoszczyznę i do Mołdawii oraz Rosji ${ }^{36}$.

Ogniskiem planowanego powstania miały być wsi Koteł i Gradec, gdzie Mamarczew przybył wczesną wiosną 1830 roku, na czele około 500-osobowego oddziału konnego. Rosjanie, którzy nie chcieli prowokować nowego konfliktu z Turcją, stanowczo sprzeciwili się samowolnej akcji swojego oficera, wysyłając w ten rejon własny 200-osobowy oddział Kozaków, który pojmał Mamarczewa, a następnie odesłał go do kwatery głównej wojsk rosyjskich. Taki był koniec bułgarskich planów powstańczych po zakończeniu wojny z lat 1828-1829. Trzeba też przyznać, że powstanie $\mathrm{w}$ istniejących warunkach nie miało szans powodzenia, nie tylko ze względu na opór Rosjan. Bułgarzy nie byli przygotowani do prowadzenia walki, brakowało broni, mundurów i innych środków na prowadzenie długookresowych działań ${ }^{37}$. Problemem była też z pewnością emigracja bułgarska w czasie i po zakończeniu wojny, gdyż znaczna część ludności opuściła ziemie rodzinne i udała się na terytorium księstw naddunajskich ${ }^{38}$. Uchodźstwo bułgarskie po wojnie 1828-1829 stanowiło zresztą największą falę emigracyjną, jaka nastąpiła w wyniku wojen rosyjsko-tureckich toczonych w XVIII i XIX wieku ${ }^{39}$. Także Mamarczew opuścił po raz kolejny ziemie bułgarskie pod koniec maja 1830 roku (tym razem zabierając ze sobą rodzinę i kilku znajomych wraz z ich bliskimi, w sumie 28 osób), przekraczając Dunaj w rejonie miast Silistra - Călăraşi ${ }^{40}$. Tutaj został aresztowany i odesłany do Bukaresztu, gdzie kolejne kilka miesięcy spędził w miejscowym więzieniu. Zwolniono go już w sierpniu 1830 roku, dzięki wstawiennictwu gen. Iwana Kiseljowa ${ }^{41}$.

36 Wedle relacji Iwana Seliminskiego, do zorganizowania powstania mieli też zachęcać Mamarczewa Polacy, oficerowie w armii rosyjskiej, oraz jeden Węgier, kwaterujący ze swoim oddziałem w pobliżu Karnobatu, który spotkał się z Mamarczewem w listopadzie 1829 roku. Zob. S. Romanski, V'staničeski načinaniya, s. 49-50.

37 Dowództwo rosyjskie już w czasie wojny nie było w stanie uzbrobić wszystkich chcących chwycić za broń Bułgarów, dostarczając tylko niewielką ilość broni palnej i szabel, stąd też zdarzały się przypadki napaści ludności cywilnej na małe jednostki tureckie i przejmowania ich uzbrojenia. Z kolei po podpisaniu pokoju adrianopolskiego władze podjęły wzmożoną akcję rekwizycyjną, przejmując broń znajdującą się w posiadaniu Bułgarów. Zob. C. Pavlovska, W"or"žavaneto v b"lgarskoto nacionalnoosvoboditelno dviženie ot načaloto na XIX vek do kraya na Krimskata voina, „Izvestiya na Voennoistoričesko naučno družestvo" 1979, t. 28, s. 77-79.

38 C. Genov, op. cit., s. 84-85.

39 Zob. K. Veliki, V. Traikov, B"lgarskata emigraciya v"v Vlahiya sled rusko-turskata voina 18281829. Sbornik ot dokumenti, Sofiya 1980.

40 Emigracja z regionu sliwenskiego była jedną z największych fal emigracji ludności bułgarskiej po zakończeniu wojny z lat 1828-1829. Tylko z tego obszaru wyjechało ponad 16 tys. osób. Akcja przesiedleńcza była wynikiem zwycięstwa opcji forsowanej przez działaczy umiarkowanych na czele z Iwanem Seliminskim, którzy stanowczo sprzeciwiali się idei wzniecenia powstania, za którą optował Mamarczew. Zob. K. Veliki, Emigriraneto na b"lgarite ot Sliven v"v Vlahiya prez 1830 godina, w: idem, Stranici ot minaloto, s. 77-111.

${ }^{41}$ K. Veliki, Neizdadeni dokumenti, s. 116-120. 
Georgi Mamarczew był też jednym z najważniejszych uczestników sprzysiężenia, przygotowującego powstanie w okręgu tyrnowskim w 1835 roku, które w rodzimej historiografii określane jest mianem Wełczowej zawery ${ }^{42}$. Nazwa tajnego porozumienia pochodzi od imienia znamienitego kupca tyrnowskiego Wełczo Atanasowa, nazywanego „Dżamadżiją” (Szklarzem), według przekazów nieco starszego od Mamarczewa, który podobnie jak on wyemigrował na ziemie rumuńskie na początku XIX wieku. W Bukareszcie, miejscu swojego osiedlenia, zetknął się z inteligencją bułgarską ${ }^{43}$, a także zdobył wiedzę i umiejętności, które po 10 latach i powrocie w rodzinne strony, pozwoliły mu zdobyć majątek i osiągnąć pozycję jednego z największych przedsiębiorców w okręgu tyrnowskim. Jednocześnie przez cały ten okres Wełczo Atanasow troszczył się o potrzeby lokalnej wspólnoty, wspierając finansowo cerkwie i monastyry, a także sprowadzając z zagranicy książki, dzięki czemu zyskał miano jednego z pierwszych księgarzy bułgarskich. Częste podróże w interesach pozwoliły mu poznać trudne warunki bytowania ludności bułgarskiej, których główną przyczynę upatrywał w polityce tureckiej względem swoich rodaków ${ }^{44}$.

Znane są nazwiska w sumie kilkudziesięciu osób zaangażowanych w organizowany zryw. Większość z nich pochodziła z Tyrnowa (dziś Wielkie Tyrnowo) oraz z miast Elena i jego okolic oraz z Trjawny ${ }^{45}$. Najważniejszymi oprócz Georgiego Mamarczewa i Wełczo Atanasowa uczestnikami tajnego porozumienia byli: mistrz Dimityr Sofijalijata (który po wybuchu miał dowodzić grupą robotników remontujących monastyr preobrażeński), Iwanaki Jonkow Kjurkczijata, Koljo Gajtandżijata, hadżi Jordan Bradata (z Eleny), nauczyciel Andon Nikopit, Siergiej - proigumen monastyru płakowskiego, mnich Teodozij oraz ojciec Zotik z monastyru preobrażeńskiego ${ }^{46}$.

Bezpośrednim impulsem do zorganizowania spisku działaczy w okręgu tyrnowskim był sukces powstania greckiego z 1821 roku i będącej jej wynikiem wojny, która umożliwiła temu państwu bałkańskiemu odzyskanie niepodległości w 1830 roku. Nie ma pewności, kiedy dokładnie uformowało się sprzysiężenie - podaje się w tym kontekście najczęściej dwie daty: 1831 lub 1834 rok, możliwe jednak, że doszło do tego jeszcze wcześniej. Nie sposób też odpowiedzieć jednoznacznie na pytanie, kto pierwszy zaproponował zorganizowanie powstania w okręgu tyrnowskim. Mógł być to Wełczo Atanasow, z drugiej strony niewykluczona jest aktywność Georgiego

42 Autor niniejszego tekstu przygotował również oddzielny artykuł poświęcony tematowi Wełczowej zawery. Zob. B. Rusin, ,, Wetczowa zawera”. Nieudana próba wzniecenia powstania na ziemiach butgarskich w 1835 roku, „Studia z Dziejów Rosji i Europy Środkowo-Wschodniej” (oddany do druku).

${ }^{43}$ Zob. E. Syupyur, B"lgarskata emigrantska inteligenciya v Rum"niya prez XIX vek, Sofiya 1982.

44 I. Džamdžiev I., Dyado Velčo i zaverata mu, w: Sbornik po slučai stogodišninata, s. 102-103.

45 Najpełniejszą jak dotąd listę, zawierającą w sumie 85 nazwisk pomieścił w swoim opracowaniu Iwan Radew. Zob. B"lgarskoto v"stanie ot 1835 g. (Velčovata zavera). Materiali i dokumenti, s"st. i red. I. Radev, Veliko T"rnovo 2000, s. 263-265.

46 Ich biogramy i materiały o charakterze wspomnieniowym w cytowanej wyżej publikacji Iwana Radewa. Zob. B"lgarskoto v"stanie ot 1835 g., passim. 
Mamarczewa w tej kwestii. Wiadomo bowiem, że jeszcze tuż po wojnie z lat 1828 1829 szukał on w tych stronach kontaktów i współpracowników, którzy pomogliby mu zorganizować powstanie i kontynuować walkę zbrojną o wyzwolenie Bułgarii. Po zwolnieniu z aresztu w Bukareszcie Mamarczew osiedlił się w Silistrze w 1831 roku, gdzie od razu wznowił swoją działalność spiskową. W tym miejscu poznał się z Wełczo Atanasowem, który podróżował po kraju w sprawach handlowych. To właśnie wtedy musiała narodzić się idea sprzysiężenia ${ }^{47}$.

Spiskowcy liczyli na uzyskanie autonomii politycznej na wzór tej, jaką ponad trzy dekady wcześniej zaproponował w swoim programie biskup Sofroniusz Wraczański ${ }^{48}$. Na ich poglądy wpływ wywarły również z pewnością memoriał do cara rosyjskiego z 1828 roku oraz nieudany plan powołania do życia okręgu autonomicznego w Dobrudży na początku lat trzydziestych XIX wieku ${ }^{49}$. Odrębne zdanie w tej kwestii wyraził w swoim artykule Petko Petkow, który stwierdza jednoznacznie, że celem Bułgarów było uzyskanie niepodległości. Stąd też postuluje on stosowanie określenia butgarska zawera, podkreślając, że spisek obejmując swoim zasięgiem rozległe terytoria w północnej części Bułgarii był w de facto ruchem o charakterze ogólnonarodowym ${ }^{50}$. Nieodzowna do tego była pomoc rosyjska, niemniej po podpisaniu pokoju adrianopolskiego we wrześniu 1829 roku, podobnie jak po zakończeniu wojny z lat 1806-1812, Rosjanie starali się utrzymywać przyjazne stosunki z Wysoką Portą. Skutkiem tego był brak wsparcia dla dążeń narodowowyzwoleńczych narodów bałkańskich, co w przypadku Bułgarii wyraziło się - we wspomnianym już wyżej - spacyfikowaniu akcji Mamarczewa w Koteł i okolicach, kiedy liczył on na kontynuowanie walki na przełomie lat dwudziestych i trzydziestych XIX stulecia.

Spiskowcy podjęli zakrojone na szeroką skalę działania - zbierano środki finansowe i broń oraz szyto mundury, zaprojektowano także specjalną odznakę oddziałów powstańczych w formie pozłacanego krzyżyka. Nie pominięto również przygotowania fizycznego i wojskowego: ćwiczono marsz, musztrę i strzelanie. By nie wzbudzać podejrzeń wszystkie te aktywności odbywały się z dala od siedzib ludzkich, uczestnicy sprzysiężenia spotykali się regularnie w małych grupach w domach prywatnych lub budynkach szkolnych, gdzie omawiali kwestie bieżące. Wraz ze zbliżaniem się terminu wybuchu powstania zintensyfikowano też agitację w Tyrnowie i całym okręgu, jak również w innych miejscowościach, gdzie mieszkali uczestnicy

47 N. Žečev, Velčovata zavera 1835. Istoričeski očerk, Sofiya 1985, s. 37-41.

48 G. Pletn'ov, I. Stoyanov, Planove i programi v nacionalnoosvoboditelnoto dviženie prez V'zraždaneto (Sbornik dokumenti), Veliko T"rnovo 1988, s. 11-13 (w języku rosyjskim); K. Veliki, Emigriraneto na B"lgarite v" v Vlahiya po vreme na rusko-turskata voina ot 1806-1812 godina, w: idem, Stranici ot minaloto, s. 35-37 (tu w języku bułgarskim).

49 V. Račeva, Otraženieto na rusko-turskata voina ot 1828-1829 g. i odrinskiyat mir ot 2 septemvri 1829 g. v"rhu B"lgarite v Dobrudža, w: Vremeto na Levski. Sbornik statii, red. P. Mitev, Sofiya 2010, S. $43-50$.

50 P. Petkov, B"lgarskata zavera ot 1835 godina - p"rva proyava na nacionalnoosvoboditelnoto dviženie prez XIX vek, „Istoričesko B”dešte” 2015, nr 1-2, s. 177-187. 
spisku, np. w mieście Elena. Sam Mamarczew krążył nieustannie po ziemiach bułgarskich, wygłaszając płomienne przemówienia i wskazując, że nadchodzi moment wyzwolenia Bułgarii spod dominacji tureckiej, w obliczu degradacji i wewnętrznego rozpadu tego „, chorego człowieka Europy” ${ }^{51}$.

Niezależnie od spiskowców z Tyrnowa do podjęcia walki zbrojnej przygotowywał się również oddział pod dowództwem Petyra Nikołajewicza, składający się z podkomendnych Mamarczewa z okresu wojny rosyjsko-tureckiej 1828-1829. Powstańcy opuścili Silistrę w marcu 1835 roku i po zaopatrzeniu się w broń z jednego ze swoich składów krążyli przez kilka miesięcy po ziemiach bułgarskich, kilkukrotnie wchodząc w drobne potyczki z Turkami. W obliczu zagrożenia postanowili z powrotem przenieść się za Dunaj, zostali jednak aresztowani przez Rosjan, a następnie odesłani pod eskortą do jednego z więzień na Wołoszczyźnie. Wkrótce podjęli próbę ucieczki, która zakończyła się częściowym sukcesem. Rosjanom udało się schwytać Nikołajewicza oraz jego dwóch braci, których wkrótce potem zesłano na Syberię w 1837 roku. Historycy bułgarscy nie ustalili, czy oddział Petyra Nikołajewicza wszedł w bezpośredni kontakt z powstańcami z Tyrnowa i okolic ${ }^{52}$. Niemniej, wskazuje się, że również Mamarczew opuścił Silistrę w tym samym czasie, tzn. pod koniec marca $1835 \mathrm{roku}^{53}$.

Przygotowania do powstania w Tyrnowie zostały udaremnione tuż przed Wielkanocą 1835 roku. W wyniku zdrady czorbadżego Jordana Kisjowa spiskowcy zostali pojmani, a następnie na najważniejszych z nich, w tym na Wełczu Atanasowie, zostały wykonane wyroki śmierci przez powieszenie ${ }^{54}$. Georgi Mamarczew, dzięki wsparciu udzielonemu przez dyplomację rosyjską, która wiedziała o bułgarskich działaniach jeszcze od pierwszej połowy lat trzydziestych, uniknął tego losu. W swojej rozmowie z rosyjskim przedstawicielem dyplomatycznym Mamarczew ukrył jednak prawdę, tłumacząc, że powodem jego wyjazdu z Silistry była chęć udania się do stolicy Imperium Osmańskiego, by wystarać się o paszport, dzięki któremu mógłby z kolei wyjechać do Rosji i tam zażądać rekompensaty za koszty poniesione w czasie wojny z lat 1828-1829. Bułgarski bojownik twierdził, że tylko przypadkiem znalazł się w okolicach Tyrnowa, w związku z prośbą o udzielenie porady ze strony miejscowej elity, której postanowił pomóc ${ }^{55}$. Po pojmaniu Mamarczewa odesłano najpierw do Widynia, a następnie do Konstantynopola, gdzie spotkał się i rozmawiał osobiście z sułtanem tureckim Mahmudem II. Wkrótce potem został zesłany, najpierw do miasta Konya w Azji Mniejszej, a następnie na wyspę Samos, gdzie pozostał do swojej śmierci w 1846 roku. Wiadomo na pewno, że podtrzymywał w tym czasie kon-

51 N. Žečev, Velčovata zavera 1835, s. 43-45.

52 I. Grek, B"lgarskite dobrovolci (volonteri) ot 1828-1829 godina, „Vekove”, 1975, t. 5, s. 8-20.

53 I. Grek, V. Červenkov, K"m istoriyata na v"or"ženoto v"stanie v B"lgaria prez p"rvata polovina na 30-te godini na XIX vek, „Vekove” 1985, t. 1, s. 43.

54 A.P. Stoilov, Krayat na velčovata zavera ot 1835 g., ,Spisanie na BAN” 1923, t. 26, s. 119-129.

55 I. Grek, V. Červenkov, op. cit., s. 44-45. 
takty z rodziną ${ }^{56}$ i przyjaciółmi, snuł też plany kontynuacji działalności rewolucyjnej w swojej korespondencji z Georgim Rakowskim ${ }^{57}$. Oprócz Mamarczewa tylko nielicznym członkom Wetczowej zawery udało się przeżyć okres tortur i szybko przeprowadzonego procesu sądowego po udaremnieniu spisku. Jednym z nich był wspomniany wyżej nauczyciel języka greckiego z Tyrnowa Andon Nikopit, którego uważa się za jednego z najważniejszych jego członków. Podobnie jak inni, po zatrzymaniu był torturowany, a następnie razem z Mamarczewem trafił do Konstantynopola, gdzie stanął przed obliczem sułtana. Po zwolnieniu z więzienia, objął Nikopit posadę nauczyciela w jednej ze szkół greckich w stolicy Imperium, a następnie po zakończeniu wojny krymskiej powrócił na ziemie bułgarskie, gdzie kontynuował działalność pedagogiczną, ucząc języka bułgarskiego i greckiego w Tyrnowie ${ }^{58}$.

Losy Mamarczewa nie były odosobnionym przykładem aktywności narodowowyzwoleńczej emigrantów bułgarskich w pierwszej połowie XIX wieku. Wielu Bułgarów włączało się aktywnie w prowadzone działania zbrojne, najczęściej jako ochotnicy w kolejnych wojnach rosyjsko-tureckich. Przykład Mamarczewa może być w tym kontekście do pewnego stopnia przypadkiem szczególnym, ze względu na fakt, że był on jednym z pierwszych Bułgarów, którzy w pełni poświęcili swoje życie walce o wyzwolenie swojego kraju z niewoli tureckiej. Na uwagę zasługuje też fakt jego zaangażowania w powstanie greckie z 1821 roku. W warunkach początku stulecia, kiedy bułgarski ruch narodowowyzwoleńczy był jeszcze niezbyt liczny i słabo zorganizowany, podjęcie tego typu aktywności było swego rodzaju novum i stanowiło wejście na kolejny etap zmagań o odnowienie bułgarskiej państwowości. Życie i działalność Mamarczewa stanowiły też inspirację dla kolejnych pokoleń Bułgarów żyjących po obu stronach Dunaju, jak było choćby w przypadku przywołanego w tekście kilkukrotnie Georgiego Rakowskiego i działaczy z jego kręgu w latach 40. 50. i 60. XIX wieku. Wtedy jednak bułgarski ruch narodowowyzwoleńczy był już na innym etapie rozwoju, a walka o wyzwolenie Bułgarii powoli wchodziła w decydującą fazę, czego skutkiem było odnowienie państwowości w 1878 roku.

\section{BIBLIOGRAFIA}

Atanasov S., Selskite v"stania v B"lgariya k"m kraya na XVIII v. i s"zdavaneto na b"lgarskata zemska voiska, Sofija 1958.

56 Zachowała się korespondencja Mamarczewa z jego synem Stefanem, którego namawiał do porzucenia życia zakonnego w Rosji i wstawienia się za nim, w celu odzyskania wolności. Ten jednak konsekwentnie odmawiał przyjścia mu z pomocą, na co wpływ mieli także hierarchowie ławry kijewsko-peczerskiej, gdzie wtedy przebywał. Zob. K. V"zv"zova-Karateodorova, Dobavki k"m biografiyata, s. $218-221$.

57 V. Traikov, op. cit., s. 58.

58 I. Boyadžiev, Edin ot r"kovoditelite na Velčovata zavera, „Istoričeski Pregled” 1978, t. 6, S. $99-102$. 
Boev R., B”lgarskiyat dobrovolčeski korpus v ruskata armiya ot 1829 g., „Voennoistoričeski sbornik” 1978 , t. 4.

Boev R., B”lgarite v rusko-turskata voina 1828 -1829 g., „Izvestiya na Nacionalniya voenno-istoričeski muzei" 1980 , t. 4.

Boev R., Antiturskoto dviženie na naselenieto ot b"lgarskoto černomorsko kraibrežie prez rusko-turskata voina 1828-1829 g., „Voennoistoričeski sbornik” 1970, t. 5.

Boyadžiev I., Edin ot r"kovoditelite na Velčovata zavera, „Istoričeski Pregled” 1978, t. 6.

Čolov P., B"lgarskite v"or"ženi četi i otryadi prez XIX vek, Sofiya 2003.

Doinov S., B"lgarite i rusko-turskite voini 1774-1856, Sofiya 1987.

Džamdžiev I., Dyado Velčo i zaverata mu, w: Sbornik po slučai stogodišninata na Zaverata ot 1835 g., Sofiya 1935.

Genov C., B"lgarite i rusko-turskite voini XVIII-XIX vek, Sofiya 1987.

Gračev V.P., K"m v"prosa za preselvaneto na b"lgari v Rusiya v načaloto na XIX v. (1800-1806), w: B "lgarskoto v"zraždane i Rusiya, red. V.D. Konobeev i dr., Sofiya 1981.

Grek I., B”lgarskite dobrovolci (volonteri) ot 1828-1829 godina, „Vekove” 1975, t. 5.

Grek I., Červenkov V., K"m istoriyata na v"or"ženoto v"stanie v B "lgaria prez p"rvata polovina na 30-te godini na XIX vek, ,Vekove” 1985, t. 1.

Jelavich B., Historia Bałkanów. Wiek XVIII i XIX, tłum. J. Polak, K. Salawa, Kraków 2005.

Konobeev V.D., B"lgarskoto nacionalnoosvoboditelno dviženie. Ideologiya, programa, razvitie, Sofiya 1972.

Korobkova N.M. (red.), Feldmaršal Kutuzov. Sbornik dokumentov i materialov, Moskva 1947.

Mitev P., Političeskata deinost na Sofronii Vračanski v konteksta na Novoto vreme, w: Sofronii Vračanskiknižovnik i politik ot novoto vreme. Sbornik s materiali ot meždunarodna naučna konferenciya, Sofiya, 24 noemvri 2011 g., red. P. Mitev, V. Račeva, Sofiya 2013.

Mutafčieva V., Vianu A., Feodalnite razmirici v Severna B"lgariya v kraya na XVIII $i$ načaloto na XIX v. i tyahnoto otraženie v"v Vlahiya, w: B"lgaro-rum"nski vr"zki i otnošeniya prez vekovete, t. 1, Sofiya 1956.

Pavlovska C., W"'or"žavaneto v b" 'lgarskoto nacionalnoosvoboditelno dviženie ot načaloto na XIX vek do kraya na Krimskata voina, „Izvestiya na Voennoistoričesko naučno družestvo” 1979, t. 28.

Petkov P., B"lgarskata zavera ot 1835 godina - p"rva proyava na nacionalnoosvoboditelnoto dviženie prez XIX vek, „Istoričesko B”dešte” 2015, nr 1-2.

Petrov A., Voina Rossii s Turciei 1806-1812 gg., t. 1-2, Sankt-Peterburg 1885, 1887.

Pletn'ov G., Stoyanov I., Planove i programi v nacionalnoosvoboditelnoto dviženie prez V"zraždaneto (Sbornik dokumenti), Veliko T"rnovo 1988.

P"rvanov I., Haiduti. B "lgarskite voivodi do kraya na XIX vek, Sofiya 2020.

Radev I. (s"st. i red.), B"lgarskoto v"stanie ot 1835 g. (Velčovata zavera). Materiali i dokumenti, Veliko T"rnovo 2000.

Rakovski G.S., S"čineniya. Proza. Poeziya, t. 1, red. K. Topalov, Sofiya 1983.

Račeva V., Otraženieto na rusko-turskata voina ot 1828-1829 g. i odrinskiyat mir ot 2 septemvri $1829 \mathrm{~g}$. v"rhu B"lgarite v Dobrudža, w: Vremeto na Levski. Sbornik statii, red. P. Mitev, Sofiya 2010.

Račeva V., Velčovata zavera (1835 g.) v ogledaloto na b"lgarskata istoriopis, w: Predizvikatelstvata na promyanata. Nacionalnata naučna konferenciya, Sofiya, 10-11 noemvri 2004, red. I. Baeva, P. Mitev, Sofiya 2006.

Račeva V., V"prositelni okolo političeska deinost na Sofronii Vračanski, „Istoriya” 1995, $\mathrm{nr} 1$.

Romanski S., Georgi Mamarčev i dobrovolčeskata mu komanda ot 1828-1829 g., „Spisanie na BAN” 1921, t. 22.

Romanski S., V'staničeski načinaniya na kapitan Goergi Mamarčev Bujukliu, w: Sbornik po slučai stogodišninata na Zaverata ot $1835 \mathrm{~g}$., Sofiya 1935.

Rusin B., „Wetczowa zawera”. Nieudana próba wywotania powstania na ziemiach butgarskich w 1835 roku, „Studia z Dziejów Rosji i Europy Środkowo-Wschodniej” (oddany do druku).

Stoilov A.P., Krayat na velčovata zavera ot 1835 g., „Spisanie na BAN” 1923, t. 26. 
Syupyur E., B"lgarskata emigrantska inteligenciya v Rum"niya prez XIX vek, Sofiya 1982.

Todorov N., Balkanski izmereniya na gr"ckoto v"stanie 1821: prinos"t na b"lgarite, Sofiya 1984.

Todorov N., Traikov V., Gr"ckoto v"stanie ot 1828-1829 g. i b”lgarite, „Istoričeski Pregled” 1971, t. 2.

Traikov V., G.S. Rakovski. Biografiya, Sofiya 1974.

Traikov V., Učastieto na b"lgarite v nacionalnoosvoboditelnite borbi na drugite balkanski narodi, w: B"lgarskata naciya prez V"zraždaneto. Sbornik ot izsledvaniya, Sofiya 1980.

Veliki K., Emigriraneto na b"lgarite ot Sliven v"v Vlahiya prez 1830 godina, w: idem, Stranici ot minaloto na b"lgarskiya narod, Sofiya 1987.

Veliki K., Emigriraneto na B"lgarite v"v Vlahiya po vreme na rusko-turskata voina ot 1806-1812 godina, w: idem, Stranici ot minaloto na b"lgarskiya narod, Sofiya 1987.

Veliki K., Neizdadeni dokumenti i nyakoi utočneniya v"v vr"zka s kapitan Georgi Mamarčev Buyuklyu, w: idem, Stranici ot minaloto na b"lgarskiya narod, Sofiya 1987.

Veliki K., Traikov V., B"lgarskata emigraciya v"v Vlahiya sled rusko-turskata voina 1828-1829. Sbornik ot dokumenti, Sofiya 1980.

V"zv"zova-Karateodorova K., Kapitan Georgi Mamarčev 1786-1846, Sofiya 1986.

V"zv"zova-Karateodorova K., Georgi Mamarčev, w: Beležiti B"lgari, t. 2, 1396-1878, red. S. Mitev, G. Gatev, G. Ginčev, N. Malčev, H. Uzunov, Sofiya 1968.

V"zv"zova-Karateodorova K., Dobavki k"m biografiyata na kapitan Georgi Mamarčev - kapitan Georgi Bujukliu (okolo 1786-1846 g.), w: V pamet na akademik Mihail Dimitrov. Izsledvaniya v"rhu B"lgarskoto v"zraždane, red. E. Stoyanova, Sofiya 1974.

Zlatarski V., Političeska rolya na Sofronii Vračanski prez rusko-turskata voina 1806-1812 g., „Godišnik na Sofiiskiya Universitet. Istoričeski Fakultet" 1923, t. 19, nr. 3.

Zlatarski V., P”rvite ,, b"lgarski deputati” $v$ Rusiya, „B"lgarska istoričeska biblioteka” 1928, t. 3.

Žečev N., B"lgarskata emigraciya v Rum"niya XIV v. - 1878 g., Sofiya 1986.

Žečev N., Velčovata zavera 1835. Istoričeski očerk, Sofiya 1985. 